\title{
Adolescence and Reward: Making Sense of Neural and Behavioral Changes Amid the Chaos
}

\author{
Deena M. Walker, ${ }^{1}$ Margaret R. Bell, ${ }^{2}$ @Cecilia Flores, ${ }^{3}$ @Joshua M. Gulley, ${ }^{4}$ Jari Willing, ${ }^{4}$ and Matthew J. Paul ${ }^{5}$ \\ ${ }^{1}$ Icahn School of Medicine at Mount Sinai, New York, New York 10029, ${ }^{2}$ DePaul University, Chicago, Illinois 60614, ${ }^{3}$ Department of Psychiatry and \\ Department of Neurology and Neurosurgery, McGill University, Douglas Mental Health University Institute, Montréal, Québec H4H 1R3, Canada, \\ ${ }^{4}$ University of Illinois, Urbana-Champaign, Champaign, Illinois 61820, and ${ }^{5}$ University at Buffalo, State University of New York, Buffalo, New York 14260
}

Adolescence is a time of significant neural and behavioral change with remarkable development in social, emotional, and cognitive skills. It is also a time of increased exploration and risk-taking (e.g., drug use). Many of these changes are thought to be the result of increased reward-value coupled with an underdeveloped inhibitory control, and thus a hypersensitivity to reward. Perturbations during adolescence can alter the developmental trajectory of the brain, resulting in long-term alterations in reward-associated behaviors. This review highlights recent developments in our understanding of how neural circuits, pubertal hormones, and environmental factors contribute to adolescent-typical reward-associated behaviors with a particular focus on sex differences, the medial prefrontal cortex, social reward, social isolation, and drug use. We then introduce a new approach that makes use of natural adaptations of seasonally breeding species to investigate the role of pubertal hormones in adolescent development. This research has only begun to parse out contributions of the many neural, endocrine, and environmental changes to the heightened reward sensitivity and increased vulnerability to mental health disorders that characterize this life stage.

Key words: drugs of abuse; medial prefrontal cortex; mesocorticolimbic dopamine pathway; puberty; sex differences; social reward

\section{Introduction}

Adolescence can be both an exciting and tumultuous time. It comprises the formative years during which individuals reach sexual maturity and develop social, emotional, and cognitive skills needed as individuals move toward independence and adulthood (Spear, 2000). It is a time of increased exploration, but this exploration often includes increased sensation seeking and the initiation of drug use (Steinberg, 2004; Lipari and JeanFrancois, 2013), which could contribute to the high percentage of preventable deaths among teens (Miniño, 2010). It is also a time of increased vulnerability to stress and the emergence of several psychiatric and behavioral disorders (e.g., schizophrenia, depression, eating disorders) (Kessler et al., 2005). Hence, research into the neurobiological underpinnings of adolescence is important for basic understanding of normative social, emotional, reproductive, and cognitive development as well as for understanding, prevention, and treatment of health risks and disorders that characterize this life stage.

The reorganization of the reward circuitry during adolescence is one factor that is integral to adolescent development and

\footnotetext{
Received Aug. 23, 2017; revised Sept. 28, 2017; accepted Sept. 28, 2017.

This work was supported by National Institutes of Health Grant R01DA029815 to J.M.G., Grant R01DA037911 to C.F., and Grant T32MH07034 to M.R.B., and the Canadian Institutes of Health Research MOP-74709 to C.F. We thank Drs. Eric Nestler (P01DA008227, R01DA007359), Janice Juraska (R21MH099625), and Cheryl Sisk (R01MH068764) for mentorship and support.

The authors declare no competing financial interests.

Correspondence should be addressed to Dr. Matthew J. Paul, Psychology Department, 204 Park Hall, University at Buffalo, State University of New York, Buffalo, NY 14260. E-mail: mjpaul@buffalo.edu.

DOI:10.1523/JNEUROSCI.1834-17.2017

Copyright $\odot 2017$ the authors $\quad 0270-6474 / 17 / 3710855-12 \$ 15.00 / 0$
}

increased vulnerability to disease (Luciana, 2013; DoremusFitzwater and Spear, 2016). This process is driven by complex interactions between neural pathways, endocrine axes, and environmental stimuli to produce a functional mesocorticolimbic reward system in adulthood. Hence, it is imperative to determine how these factors act independently and in concert to shape the mesocorticolimbic reward circuitry during adolescence. This review highlights research on interactions between the mesocorticolimbic dopamine (DA) system, pubertal hormones, and environmental perturbations (drug use and social stress) and their effects on cognitive and social adolescent development.

\section{Puberty-dependent and puberty-independent}

adolescent development

Puberty and adolescence both refer to the transition from childhood to adulthood, but these terms are not equivalent. Puberty is reserved for physiological and behavioral changes associated with the attainment of reproductive competence (e.g., activation of the hypothalamic-pituitary-gonadal [HPG] axis, appearance of secondary sex characteristics, and onset of sexual interest and mating behaviors). Adolescence is a broader term that includes puberty as well as nonreproductive traits (e.g., social, emotional, and cognitive development). Reproductive hormones, however, can have widespread effects, and the development of several nonreproductive adolescent traits can also be driven by activation of the HPG axis at puberty (puberty-dependent; e.g., ethanol intake, anxiety-related behaviors) (Primus and Kellogg, 1989, 1990; Vetter-O'Hagen and Spear, 2011). The different physiological, anatomical, and temporal changes of puberty between males and females can also lead to the emergence of sex differences during 
adolescence (Schulz et al., 2009). Other adolescent traits, however, develop independently of HPG activation and merely coincide with pubertal development (puberty-independent; e.g., social play, aggression) (Whitsett, 1975; Smith et al., 1996; Wommack and Delville, 2007). Sex differences may also manifest in puberty-independent traits due to organizational actions of perinatal hormones or direct actions of genes on the sex chromosomes (Arnold, 2017). This puberty-dependent versus puberty-independent distinction is important because many neuropsychiatric and behavioral disorders arise during adolescence, exhibit striking sex differences, and are impacted by pubertal hormones as well as nonpubertal factors (Fombonne, 2009; Graber, 2013; Trotman et al., 2013). Given that the mesocorticolimbic DA pathway is sexually dimorphic (Becker, 2009) and regulated by gonadal hormones in adults (Kuhn et al., 2010; Becker et al., 2012), a central question is whether adolescent development of reward-related behaviors and circuitry is puberty-dependent or puberty-independent.

\section{Sex differences in reward and reward-related circuitry}

Studies in humans and laboratory animals generally support the notion that adolescents are more sensitive to reward than adults. This is behaviorally manifest in multiple ways, including elevated levels of sensation seeking and risk taking, as well as reduced inhibitory control, which are maximal during the early to midadolescent period (Burnett et al., 2010; Andrzejewski et al., 2011; Burton and Fletcher, 2012; Urošević et al., 2012; Collado et al., 2014). In laboratory rodents, heightened reactivity to drug rewards has also been demonstrated (Doremus et al., 2005; Levin et al., 2007; Anker and Carroll, 2010), although this might depend on the drug or other procedural factors (Doremus-Fitzwater and Spear, 2016). When gender or sex is considered, an even more nuanced picture emerges. For example, compared with males, females have a relatively earlier and lower magnitude peak in sensation seeking during mid-adolescence that is followed by a more rapid decline to stability by early adulthood (Shulman et al., 2015). In this comprehensive, longitudinal study, it was also demonstrated that impulse control improved steadily following early adolescence, but males remained more impulsive than females through their mid-20s. In rats, male adolescents exhibit greater intake and motivation for palatable food that is either calorie dense (sweetened condensed milk) (Friemel et al., 2010) or calorie devoid (Marshall et al., 2017), compared with adults. However, this age-dependent difference in reward sensitivity was not apparent in female rats (Marshall et al., 2017). Using foodrestricted rats trained to associate a tone with delivery of a sucrose solution, Hammerslag and Gulley (2014) found that the effects of age and sex were dependent on the characteristics of the behavior being measured. Specifically, females exhibited enhanced development of stimulus-directed behavior in that both adult and adolescent females acquired Pavlovian approach more quickly than males. Adolescents of both sexes, however, had weaker expression of goal-directed behavior (i.e., entries into the sucrose delivery trough) and were less sensitive to reward devaluation than adults.

Recent work has also highlighted gender and sex differences in neural development of reward-related brain circuits that may play an important role in these age and gender/sex differences in behavior. In the striatum, adolescent boys lag behind as they reach peak striatal volume at $\sim 15$ years of age compared with 12 for girls (Raznahan et al., 2014). Structural development in the cortex also appears relatively delayed in boys compared with girls, although exceptions include a more rapid reduction in the thick- ness of the dorsolateral PFC in males (Raznahan et al., 2010). Many of these adolescent cortical changes are associated with adrenal and/or gonadal markers of pubertal maturation, often in a sex-dependent manner (e.g., Herting et al., 2014, 2017). In the rat $\mathrm{mPFC}$, there are significant decreases in neuron number (Markham et al., 2007), dendritic complexity (Koss et al., 2014), and synapse number (Drzewiecki et al., 2016) between adolescence and adulthood. At least some of these changes are more pronounced in females compared with males and are closely linked to puberty onset (Willing and Juraska, 2015). In the core and shell regions of the NAc, these "pruning" processes and the emergence of adult-like morphological features appear to occur much earlier and well before the onset of puberty (Tepper et al., 1998; Lee and Sawatari, 2011).

\section{Development of the PFC during adolescence}

The $\mathrm{mPFC}$ is a crucial regulator of reward-directed behaviors and likely contributes to cognitive development during adolescence. As a major component of the mesocorticolimbic DA pathway, it receives dopaminergic projections from the VTA and sends key glutamatergic projections to the NAc, a key integrator of reward processing (Albertin et al., 2000; McGinty and Grace, 2009; Hamel et al., 2017; Morrison et al., 2017). These regions form a larger circuitry that includes the BLA and ventral hippocampus, among others (Fig. 1). This circuit acts in concert to modulate dopaminergic and glutamatergic tone integrated by the NAc in response to salient stimuli. Loss or reduction of signaling within the PFC in humans has been associated with numerous psychiatric disorders, including anxiety and depression (Ressler and Mayberg, 2007) and substance use disorders (Volkow et al., 2010) in adulthood. Similar effects have been observed in rodent models where exposure to stress or drugs of abuse can influence signaling between the PFC and NAc, resulting in addiction-related behaviors (MacAskill et al., 2014) or depressive-related behaviors (Covington et al., 2010; Vialou et al., 2014; Bagot et al., 2015). For example, repeated exposure to cocaine in adult mice decreases the PFC inputs to D1 DA receptor containing medium spiny neurons in the NAc (MacAskill et al., 2014).

One of the most dramatic brain changes occurring during adolescence is the unfolding of DA connectivity in the mPFC. In contrast to DA projections to limbic regions (e.g., NAc) and cortical innervation of other monoamines (e.g., norepinephrine and serotonin) that reach adult density levels early in life (Coyle and Molliver, 1977; Levitt and Moore, 1979; Lidov et al., 1980; Benes et al., 2000; Diamond, 2002), DA projections to the mPFC do not fully mature until early adulthood (Kalsbeek et al., 1988; Benes et al., 2000; Manitt et al., 2011; Naneix et al., 2012). In rodent models, the number of dopaminergic fibers in the mPFC increases linearly between the juvenile period (postnatal day $[\mathrm{P}] 25$ ) and young adulthood, with the most prominent increases occurring between the late juvenile period and early adulthood (Naneix et al., 2012; Willing et al., 2017). Interestingly, this is not a rodentspecific phenomenon as protracted mesocortical DA development occurs in nonhumans primates and most likely in humans (Rosenberg and Lewis, 1994; Lambe et al., 2000), paralleling cognitive maturation.

In addition to changes in dopaminergic projections in adolescence, changes in dopaminergic receptor expression are prevalent throughout the mesocorticolimbic system, which may underlie the altered sensitivity to rewarding stimuli. In the NAc and dorsal striatum, DA D1 and D2 receptor expression peaks during adolescence (P40), then declines to reach adult levels $\sim$ P80 (Andersen et al., 2000). In the PFC of rats, there is also 


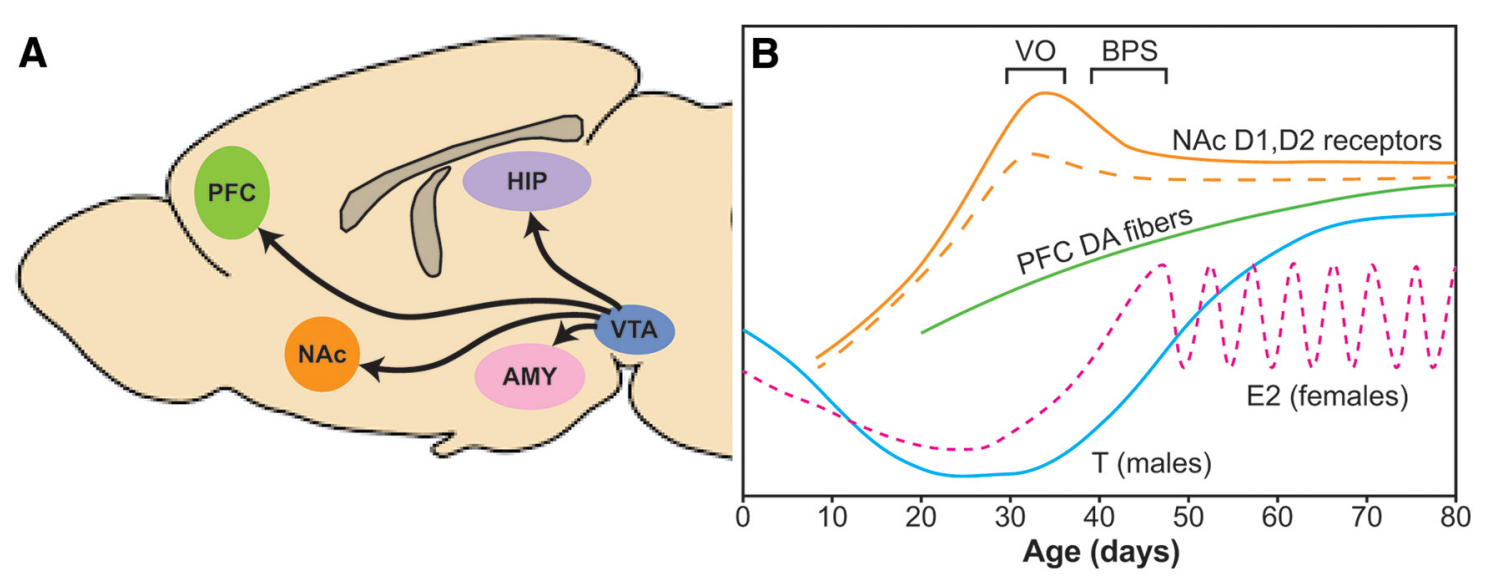

Figure 1. Adolescent development of the mesocorticolimbic DA pathway. $A$, Major brain areas and projections of the mesocorticolimbic DA pathway. $B$, A schematic of postnatal development of key components of this pathway along with changes in gonadal steroid hormones and pubertal markers. Hashed lines indicate data specific to females. Developmental patterns and markers are based on data from Tarazi and Baldessarini (2000) (NAc D1, D2 receptors); Naneix et al. (2012) and Willing et al. (2017) (PFC DA fibers); and Döhler and Wuttke (1975) and Vetter-0'Hagen and Spear (2012a) (gonadal steroid concentrations and pubertal markers). V0, Vaginal opening; BPS, balano-preputial separation; E2, estradiol; T, testosterone.

a selective decrease of cells expressing D1 receptors that project to the NAc between P44 and adulthood (Brenhouse et al., 2008). However, there may be important species differences in these receptor changes across adolescence (Pokinko et al., 2017).

Measures of functional connectivity in humans have further elucidated the widespread changes between the PFC and subcortical structures throughout adolescence, with some evidence suggesting that a relatively stable network connectivity state does not occur until at least the mid-20s (Dosenbach et al., 2010). The potential relevance of these changes for behavior is not fully understood, but decreases in the functional coupling between subregions of the PFC and the NAc have been linked with decreases in self-reported risky behavior across adolescence $(\mathrm{Qu}$ et al., 2015). Interestingly, studies of PFC activation in humans have revealed sex differences in function that go beyond what might be expected from the anatomical correlates. One such functional development is resting state functional connectivity, which describes the degree of synchrony between two different brain regions or between nearby areas within a brain region. In the dorsolateral PFC, resting state functional connectivity between the hemispheres tends to increase with age in males but decreases with age in females (Zuo et al., 2010).

These data demonstrate that the mesocorticolimbic DA pathway undergoes vast developmental changes during adolescence both in fiber projections to the PFC and in sensitivity to DA within the NAc, dorsal striatum, and PFC target areas through altered receptor expression. Some of these developmental changes seem to occur independent of the gonadal hormone surge associated with puberty (Andersen et al., 2000; Willing et al., 2017). Although tyrosine hydroxylase-immunoreactivity in the PFC increases across adolescence, this increase does not appear to be associated with markers of pubertal status (Willing et al., 2017). Preventing the pubertal rise in gonadal hormones by gonadectomy on P28 does not alter the adolescent (P40) or adult (P80) levels of D1 or D2 receptor expression in the rat striatum (Andersen et al., 2000). Finally, many developmental changes occur before puberty (e.g., adult-like morphological features of striatal neurons) (Tepper et al., 1998; Lee and Sawatari, 2011). For many measures, more research is needed to answer this question. The influence of gonadal hormones on reward-associated behaviors and the mesocorticolimbic pathway in adults (Becker et al., 2012) suggests at least a modulatory role during adolescence, particu- larly with respect to the emergence of sex differences (Kuhn et al., 2010).

\section{Pubertal influences on mPFC adolescent development}

Recent evidence suggests that, within the adolescent period, pubertal onset may be particularly critical in specific aspects of mPFC development and cognition. Previous work in rats has documented a reduction in mPFC volume between the juvenile and adult periods (Van Eden and Uylings, 1985), and this volumetric reduction may reflect a decrease in neuron number. Stereological quantification of the total number of neurons in the mPFC across adolescence revealed that the majority of neuronal losses occur during the period of pubertal onset, particularly in female rats (Willing and Juraska, 2015). Ovariectomy before puberty prevented these neuronal losses, further suggesting a role for pubertal hormones (Koss et al., 2015). Additionally, there are changes in dendritic complexity and synapse number in the mPFC during adolescence. Between P35 and P90, there is a reduction in dendritic spine density in both male and female rats (Koss et al., 2014). In a recent study, Drzewiecki et al. (2016) conducted an immunohistochemical analysis of synaptophysin as a marker for total synapse number in the mPFC in P25, P35, $\mathrm{P} 45, \mathrm{P} 60$, and $\mathrm{P} 90$ rats of both sexes. As expected, there was evidence for significant synaptic pruning during adolescence. Interestingly, a direct comparison of prepubertal versus postpubertal females at P35 and prepubertal versus postpubertal males at P45 (corresponding to the average age of pubertal onset) revealed that, in both sexes, postpubertal animals had significantly fewer synapses than their prepubertal counterparts.

These structural alterations within the mPFC are associated with changes in cognitive performance during adolescence, which also seem to depend on the timing of puberty. These differences in cognitive performance could reflect differences in reward processing. Indeed, substance use disorder is often described as maladaptive decision-making and reward learning. Given the importance of the entire PFC in reward learning, it follows that structural changes in adolescence result in altered cognitive performance and decision making with regard to reward. Kanit et al. (2000) found that pubertal onset alters learning strategies in spatial memory tasks. However, there is a paucity of research that accounts for a potential role for puberty, particularly on mPFCdependent tasks. Willing et al. (2016) have recently shown that 
pubertal onset leads to better performance on an mPFCmediated cognitive flexibility component of a Morris Water Maze task in both male and female rats. Path length to the novel platform location was shorter in postpubertal males and females, and prepubertal animals spent a greater amount of time swimming in the quadrant where the platform was initially located, suggesting a deficit in cognitive flexibility that subsides after pubertal onset. Future studies are needed to determine whether these temporal associations with pubertal status reflect pubertal mechanisms or coincidental timing. Recent studies in female mice support the former. Preventing the pubertal rise in ovarian hormones by prepubertal gonadectomy blocks adolescent maturation of inhibitory neurotransmission in the frontal cortex (Piekarski et al., 2017). Conversely, advancing puberty by prepubertal estradiol and progesterone treatment accelerates the maturation of this inhibitory tone in the frontal cortex and developmental increases in cognitive flexibility (Piekarski et al., 2017).

Disruption of adolescent PFC development by drugs of abuse The initiation of consumption of drugs of abuse is an adolescent phenomenon, with $>50 \%$ of individuals taking drugs for the first time being below the age of 18 years (Johnston and Coplin, 1979; Warner et al., 1995; Grant, 1997; Degenhardt et al., 2007; Elgar et al., 2011; Currie and Wild, 2012; Leatherdale and Burkhalter, 2012; Swendsen et al., 2012). Starting drug use during adolescence increases the risk of abuse across the lifetime, with greater vulnerability conferred to younger initiates (Robins and Przybeck, 1985; Grant and Dawson, 1998; Compton et al., 2007; Hasin et al., 2007; McCabe et al., 2007; Chen et al., 2009; Palmer et al., 2009; Swendsen et al., 2012). Significant efforts are being made to develop prevention and early intervention/treatment programs. However, the more we learn about the molecular processes that occur in the adolescent brain and about how these may be influenced by drugs of abuse, the more effective such programs will be.

As mentioned above, innervation of the PFC by dopaminergic neurons from the VTA occurs during adolescence. Reynolds et al. (2017) recently showed that, in rodents, delayed development of the mesocortical DA innervation does not result from sprouting of DA fibers that reach this region early in life. Instead, they demonstrated that DA axons continue to grow from the NAc to the PFC during adolescence. Indeed, this is the only known case of long-distance axon growth during this late postnatal age. Netrin-1 guidance cue receptor, DCC, controls this growth by promoting axon targeting events in the NAc, in turn delimiting the number of axons that continue to extend to the cortex. Alterations in DCC expression in DA neurons in adolescence changes the number of axons that continue to extend from the NAc to the PFC and consequently the organization of DA synaptic networks (Manitt et al., 2011, 2013; Reynolds et al., 2017). Importantly, by orchestrating DA connectivity in adolescence, DCC receptors determine the intrinsic structural and functional maturation of the PFC itself (Manitt et al., 2011, 2013; Reynolds et al., 2017). These findings indicate that (1) the path finding trajectory of DA axons remains vulnerable throughout adolescence, and (2) environmental factors that alter DCC receptor expression in DA neurons in adolescence could profoundly influence PFC development.

Indeed, exposure to amphetamine in early adolescence at doses that are equivalent to those abused in humans downregulates DCC receptor expression in DA neurons. In turn, this same amphetamine regimen leads to a significant increase in the extent of the DA projections to the PFC but depletes mesocortical axons of presynaptic sites (Reynolds et al., 2015). These enduring effects are not observed following adult exposure to amphetamine, indicating that amphetamine in adolescence disrupts mesocortical DA development via the DCC pathway. Consistent with the determinant role that the mesocortical DA innervation plays on cognitive maturation, we find that amphetamine in adolescence negatively influences cognitive processing in adulthood (Reynolds et al., 2015). Mice exposed to a similar amphetamine treatment in adolescence, but not in adulthood, show exaggerated salience attribution to stimuli paired with the drug and deficits in behavioral inhibition. Age of exposure-dependent effects of amphetamine on cognition has also been seen in rats (Hankosky et al., 2013; Sherrill et al., 2013) and may be sex-dependent (Hammerslag et al., 2014). These changes in salience attribution and cognitive inhibition resemble those observed across psychiatric conditions of PFC dysfunction, including drug abuse.

\section{Development of social reward during adolescence}

The adolescent transition from childhood to adulthood requires a qualitative shift in the perception of rewarding social interactions (Spear, 2000). In humans, adolescence is characterized by increases in time spent with peers and changes in the quality of social interactions with family and peers (Larson et al., 1996). Adolescents rely on their contemporaries for social support and are increasingly reactive to treatment by their peers (Ladd et al., 2014). These social relationships influence the development and maintenance of maladaptive behaviors in adulthood (Patterson et al., 1992; Hankin et al., 1998). Indeed, peer influence is a strong predictor of adolescent depression (Thapar et al., 2012). This reorganization of social structure during adolescence is necessary for social species to develop appropriate behavioral strategies for survival in adulthood (Gopnik et al., 2017). A close association between adolescent social reorganization and puberty is thought to increase exposure to genetically distinct individuals when sexual behavior emerges, thereby decreasing the chance of inbreeding within a social group (Lawson Handley and Perrin, 2007).

As in humans, adolescent changes in social interactions and social structure are prevalent in rodents. Adolescent rats place a greater value on peer-directed activities (Pellis and Pellis, 2017) and exhibit a greater preference for social stimuli in a conditioned place preference (CPP) test compared with adults (Douglas et al., 2004; Yates et al., 2013), suggesting that the adolescent rodent brain is highly sensitive to social reward. It is thought that adolescent-specific social experiences result in permanent neural and hormonal changes that coalesce in cognitive strategies, which lead to effective coping in adulthood (Spear, 2000).

The limbic system is a known regulator of social interaction and social reward. In particular, the amygdala is critically important for the integration of emotional stimuli and regulates emotional and motivated behaviors (Wassum and Izquierdo, 2015). The BLA in particular has been studied extensively for its role in reward because it is thought to be important in assessing/assigning value to stimuli and is a key regulator of social interactions. Activation of the BLA reduces social interaction (Sanders and Shekhar, 1995), whereas inhibition of glutamatergic or GABAergic transmission within the BLA increases social interactions (Sajdyk and Shekhar, 1997; Paine et al., 2017). Projections from the BLA to PFC likely contribute to this social regulation as selective activation of these projections decreases social behaviors (Felix-Ortiz et al., 2016). In addition to its reciprocal glutamatergic projections with the PFC, the BLA projects to the NAc and receives dopaminergic projections from the VTA (Wassum and Izquierdo, 2015). Each of these circuits develops at different 
stages (Bouwmeester et al., 2002a, b; Cunningham et al., 2002; Caballero et al., 2014; Wassum and Izquierdo, 2015; ArrudaCarvalho et al., 2017). For example, projections from the PFC to BLA are established between P10 and P15 (Bouwmeester et al., 2002b; Arruda-Carvalho et al., 2017), but the reciprocal projections (BLA to PFC) are established a few days earlier (Bouwmeester et al., 2002a; Cunningham et al., 2002). The amygdalar circuit (including NAc, VTA, PFC, and ventral hippocampus) develops during the juvenile/early adolescent period, and synapses are established by the second or third postnatal week. Although projections within the amygdalar circuitry are established before adolescence, recent evidence suggests that the PFC to BLA projections undergo significant synaptic strengthening (as measured by IPSC/EPSC ratio) on P30 (Arruda-Carvalho et al., 2017), and there are more PFC to BLA projections on P31 compared with P24 and P45 (Pattwell et al., 2016), suggesting that this point in adolescence may be a crucial developmental period for limbic structures. The amygdala (Meaney et al., 1981; Meaney and McEwen, 1986; Jessen et al., 2010), and BLA in particular (Trezza et al., 2012; Achterberg et al., 2015), are important regulators of social play, a prominent juvenile social behavior that is important for social, emotional, and cognitive development (Pellegrini, 1988; Vanderschuren et al., 1997; van den Berg et al., 1999; Baarendse et al., 2013). Notably, the PFC-BLA synaptic development coincides with the developmental rise in this behavior (Panksepp, 1981).

\section{Gonadal hormonal influences on adolescent reward valiance}

Social interactions in adolescence are not limited to same sex conspecifics. As juveniles proceed through adolescence, interactions with opposite sex conspecifics, and ultimately copulation, become motivating and rewarding stimuli. The performance of sexual behavior may increase risk of aggressive and predatory encounter (Kavaliers and Choleris, 2001), but is also a strong natural reward (Trezza et al., 2011). Thus, it is possible that the neural developmental processes that promote adaptive rewarding social interactions also contribute to risk taking behavior that increases during human adolescence. As mentioned above, adolescent rodents display a greater preference for social stimuli in a CPP paradigm (Douglas et al., 2004; Yates et al., 2013). However, attempts to compare reactions of juvenile and adult animals to potentially rewarding social interactions can be confounded by the conspecific stimulus animal behaving differently toward juveniles and adults. This concern is alleviated by using a social cue, such as opposite sex odors, which can be presented in place of the behaving stimulus animal. The male Syrian hamster provides a unique model for understanding how the perception of potentially rewarding social cues matures across adolescence because their attraction to female vaginal secretions (VSs), which are essential for adult sexual behavior, develops across adolescence (Murphy and Schneider, 1970; Johnston, 1986).

VSs are an unconditioned reward to sex-naive adult male hamsters in a CPP test (Bell et al., 2010). Importantly, this same chemosensory cue is not attractive (Johnston and Coplin, 1979) or rewarding (Bell et al., 2013b) to juvenile animals. Like the performance of sex behavior, the rewarding perception of VSs is dependent on circulating testosterone: adult animals that were gonadectomized 10 weeks prior did not show CPP to VSs (Bell and Sisk, 2013). This suggests that the increase in gonadal hormones during puberty normally promotes this adolescent shift in cue interpretation. Indeed, treating juvenile Syrian hamsters with testosterone induces CPP to VS weeks earlier than in unmanipu- lated hamsters (Bell et al., 2013a), indicating that the shift in VS reward valence is indeed puberty-dependent.

The neural circuitry for this shift in behavior includes many of the same brain regions and neurotransmitters involved in drugs of abuse. The display of CPP for VSs in testosterone-treated juvenile animals is blocked by systemic haloperidol, a DA receptor antagonist (Bell and Sisk, 2013). VSs induce expression of the immediate early gene Fos throughout hypothalamic and amygdalar brain regions normally implicated in sociosexual behavior and chemosensory cues equally between juvenile and adult Syrian hamsters (Romeo et al., 1998). However, adult, but not juvenile, males show Fos responses to VS in subregions of the PFC and dopaminergic and nondopaminergic cells in the VTA (Bell et al., 2013b). These immature Fos responses are not transformed into adult-like patterns by testosterone treatment of juvenile males (Bell et al., 2013a). In parallel, testosterone treatment does not induce sex behavior in juvenile animals (Schulz et al., 2009). Perhaps puberty-independent maturation of the mesocorticolimbic system is necessary for the full complement of sociosexual behavior. Complex behaviors are mediated by a suite of brain regions, which may be differentially hormone sensitive. As such, major changes in behavior are likely affected by both pubertydependent and puberty-independent mechanisms.

\section{Adolescent social stress affects adult reward-associated behaviors and brain regions}

Adversity during the adolescent period increases the risk for numerous psychiatric disorders in adulthood, including depression (Heim et al., 2008), anxiety (Espejo et al., 2007), substance use disorders (Scheller-Gilkey et al., 2003), and schizophrenia (Holtzman et al., 2013). Manipulation of the social experience in adolescent rodents results in long-term alterations in the behavioral correlates of anxiety, depression, and substance use disorders (Burke et al., 2017), thereby providing a valuable model in which to investigate the cellular and molecular underpinnings of susceptibility to psychiatric disorders.

Specifically, adolescent social isolation stress (aSI) is commonly used to induce susceptibility to substance use disorders as well as anxiety- and depression-like behaviors in adult rodents (Burke et al., 2017). Given its prevalence as a model, it would be beyond the scope of this review to provide a comprehensive overview of the effects of aSI on reward-associated development. However, this manipulation consistently enhances self-administration and CPP for numerous drugs of abuse and natural reward in males (Smith et al., 1997; Howes et al., 2000; Brenes and Fornaguera, 2008; Whitaker et al., 2013), alters social and emotional processing (Einon and Morgan, 1977; Arakawa, 2003; Lukkes et al., 2009b), and increases fear- and anxiety-related behaviors (Einon and Morgan, 1977; Wright et al., 1991a; Wilkinson et al., 1994; Lukkes et al., 2009a; Chappell et al., 2013) in adult rodents. In addition, aSI is associated with changes in gene expression and protein throughout the mesocorticolimbic system (Lukkes et al., 2009b, 2013; Donner et al., 2012; Hickey et al., 2012; Whitaker et al., 2013), in neuronal development and monoaminergic activity in the NAc, BLA, and PFC (Wright et al., 1991b; Fulford and Marsden, 1998a, b; Brenes and Fornaguera, 2008; Brenes et al., 2008; Lukkes et al., 2008, 2009c, 2013; Fabricius et al., 2011) and in electrophysiological properties within the VTA, hippocampus (HIP), and PFC (Peters and O'Donnell, 2005; Ashby et al., 2010; Whitaker et al., 2013). Although it is clear that aSI has profound effects on mesocorticolimbic development and function, to our knowledge, whether these effects are dependent on the pubertal hormone surge and how aSI might alter hormonal influences of 
A

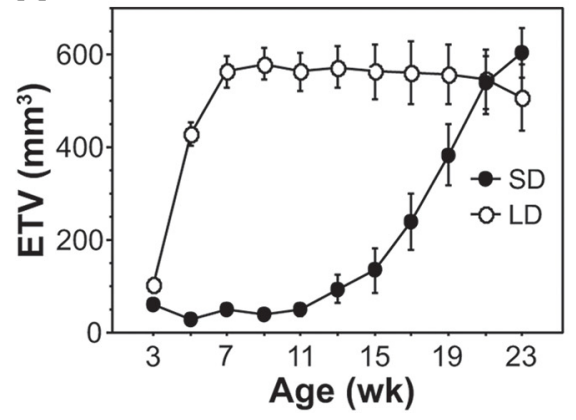

B

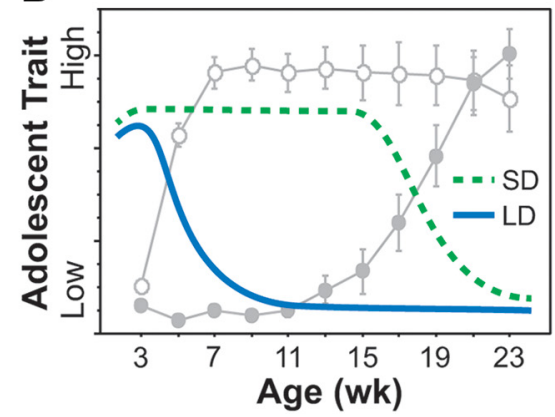

C

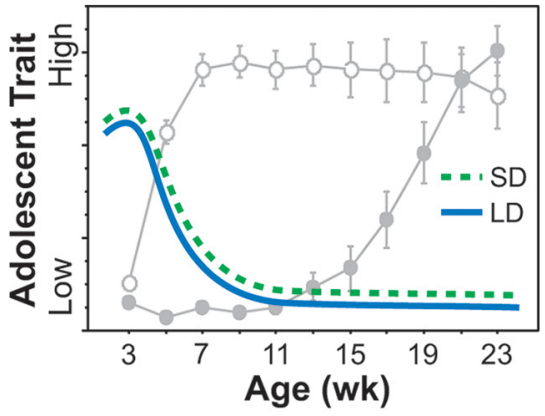

Figure 2. Using seasonal breeders to separate puberty-dependent and puberty-independent influences on adolescent development. $\boldsymbol{A}$, Photoperiod regulation of puberty in male Siberian hamsters: LDs stimulate, whereas SDs delay, testicular development. $\boldsymbol{B}, \boldsymbol{C}$, How this model can be used to determine whether the development of an adolescent trait is regulated by pubertydependent or puberty-independent mechanisms. Solid blue line indicates the developmental profile of a hypothetical trait for LD-reared hamsters. Dashed green line indicates the developmental profile of a hypothetical trait for SD-reared hamsters. Delayed development of the adolescent trait in SD-reared hamsters (as in $\boldsymbol{B}$ ) maintains temporal synchrony with puberty and indicates puberty-dependent regulation. Absence of a photoperiod effect on the adolescent trait (as in $\mathbf{C}$ ), however, dissociates the trait from puberty in SD-reared hamsters and indicates pubertyindependent regulation. ETV, Estimated testis volume. Illustration of testis data modified with permission from Paul et al. (2006).

mesocorticolimbic processing have not been investigated. Shipping stress and immune challenge during puberty blunt the antidepressant and anxiolytic effects of estradiol and alter microglia activation in the amygdala (AMY) and HIP of adult female rats (Ismail and Blaustein, 2013; Ismail et al., 2013; Holder and Blaustein, 2017). This research offers intriguing evidence that at least nonsocial stressors during adolescence can alter hormonal influences on affective behaviors and neural circuitry in adulthood.

Much of the work investigating aSI on reward-associated behaviors has focused on male rodents (Cooke et al., 2000) and the traditional reward-associated brain regions, including the $\mathrm{MPFC}$, NAc, VTA, and BLA (Lukkes et al., 2009b). Nevertheless, females are sensitive to aSI, and the mechanisms underlying their sensitivity are beginning to be investigated (Burke et al., 2017). Initial studies suggest that the effect of aSI on reward-associated behaviors in females is opposite from those in males. As predicted, male mice isolated from P22-P42 display a greater preference for cocaine in a CPP paradigm compared with nonisolates. Females, however, show a reduced preference. aSI also reversed the sex difference in cocaine preference (females $>$ males under control conditions) and markedly reduced or reversed known sex differences in baseline anxiety-like behaviors in adulthood (D. M. Walker and E. J. Nestler, unpublished data). Current research is investigating circuitwide transcriptomic and projection-specific changes altered by aSI to understand how the mesocorticolimbic circuitry is "organized" during adolescence in a sex-specific manner.

Brain areas outside the canonical reward-associated circuitry are also likely to play a role in sex differences in aSI, particularly those that are hormone sensitive, sexually dimorphic, and send projections to brain areas of the mesocorticolimbic pathway. The medial AMY (meAMY) is larger in males than in females (Hines et al., 1992; Kerchner et al., 1995). However, unlike most sexually dimorphic brain regions, sex differences in volume of subnuclei within the meAMY do not emerge until adolescence, and the pubertal testosterone surge in males contributes to the organization of this sex difference (De Lorme et al., 2012). This change in meAMY structure co-occurs with changes in rewarding sociosexual behaviors that are in part regulated by it (De Lorme et al., 2012). However, little is known about the role of the meAMY in drug-related reward (Knapska et al., 2007); and to our knowledge, only one study has investigated its role in cocaine selfadministration (Kuzmin and Johansson, 1999). Additionally, adolescent stress dysmasculinizes the meAMY: meAMY volume and cell number are decreased in males stressed during adolescence compared with their control counterparts, and these stressed males are less efficient at mating (Cooke et al., 2000). Collectively, this literature suggests that the meAMY contributes to the development, initiation, and maintenance of sex differences in reward and motivation. Consistent with this hypothesis, initial experiments have found that aSI not only reversed known sexually dimorphic behaviors but also reversed sex differences in gene expression throughout the reward circuitry with the strongest effects observed in the meAMY. Furthermore, the sex difference in the number of projections from the meAMY to the VTA is lost after aSI (Walker and Nestler, unpublished data), suggesting that the emergence of many sex differences in meAMY during adolescence are affected by social cues and could be crucial for the manifestation of sex differences in motivation and reward in adulthood.

\section{Exploiting seasonal physiology to separate puberty-dependent and puberty-independent influences on adolescent reward} As discussed in this review, the development of reward-associated behaviors and circuitry is influenced by both puberty-dependent and puberty-independent mechanisms. Disentangling contributions from puberty-dependent and puberty-independent processes, however, is often difficult. Traditional approaches to this question fall under two categories. The first asks whether gonadal hormone manipulations alter the timing of adolescent development: Does gonadectomy prevent, and hormone replacement restore, adolescent changes? The second approach asks whether adolescent changes correlate with chronological age or pubertal status. This second approach is often difficult because, in most models, puberty is tightly correlated with chronological age leading to small age differences among conspecifics in the timing of pubertal development. Seasonally breeding species could provide an alternate approach to investigate puberty-dependent and puberty-independent influences on adolescent development; one that uses natural adaptations to dissociate pubertal development from chronological age in structurally and genetically intact animals. For many seasonally breeding rodents, offspring born early in the breeding season (spring and early summer) undergo rapid pubertal development to breed that same year, whereas those born at the end of the breeding season (autumn) delay puberty during the winter months to synchronize the onset of breeding 
with the following spring (Sadleir, 1969). Day length serves as a proximate cue for time of year in many seasonally breeding species (Paul et al., 2008; Stevenson et al., 2017). Hence, seasonal regulation of pubertal development can be recapitulated in the laboratory simply by manipulating the ambient photoperiod: long, summer-like day lengths (LDs) stimulate rapid pubertal development, whereas short, winter-like day lengths (SDs) delay pubertal development (Whitsett and Miller, 1982; Yellon and Goldman, 1984; Edmonds and Stetson, 1993; Nelson et al., 1997). In Siberian hamsters (Phodopus sungorus), SD rearing delays puberty by 3-5 months (Hoffmann, 1978) (Fig. 2A). Hence, in seasonal species, one can systematically control the timing of puberty with photoperiod and ask whether the development of nonreproductive adolescent traits is similarly delayed by SD rearing (puberty-dependent; Fig. $2 B$ ) or unaffected by ambient photoperiod (puberty-independent; Fig. 2C).

It should be noted that the seasonal species approach asks a slightly different question than the gonadal hormone approach. Manipulating gonadal hormones during adolescence directly tests the role of increased gonadal hormones at puberty, whereas shifting the timing of puberty with photoperiod tests the role of pubertal activation of the entire HPG axis. Indeed, gonadectomy does not prevent pubertal onset: activation of the hypothalamic $\mathrm{GnRH}$ pulse generator and increased secretion of pituitary gonadotropins at puberty occur even in the absence of the gonads (Ojeda and Terasawa, 2002). The seasonal species approach circumvents potential confounds of the gonadal hormone approach, including early-life surgical/handling stress (VetterO'Hagen and Spear, 2011; Pritchard et al., 2012; Vetter-O'Hagen and Spear, 2012b; Farrell et al., 2016) and compensatory changes in the brain and pituitary after removal of gonadal steroid feedback (Meijs-Roelofs and Kramer, 1979; Andrews and Ojeda, 1981; Bittman et al., 1996; Dubois et al., 2016). On the other hand, photoperiod can influence more than just puberty in seasonal species (Paul et al., 2008; Stevenson et al., 2017), and contributions from other seasonal traits must be considered if there is an effect of photoperiod on adolescent development (as in Fig. 2B). This is not an issue if photoperiod does not influence the development of the adolescent trait (as in Fig. 2C). Hence, the two approaches complement each other and are best used in combination.

Experiments using Siberian hamsters have begun to test the seasonal species approach on the development of two rewardassociated behaviors: one thought to be regulated by pubertyindependent mechanisms: social play (Smith et al., 1996); and another for which the data are mixed: novelty seeking (Cyrenne and Brown, 2011; Vetter-O'Hagen and Spear, 2012a). Juvenile rats can be conditioned to prefer a location in which they previously played (Calcagnetti and Schechter, 1992; Trezza et al., 2009) and will work for access to a playmate (Achterberg et al., 2016). Hence, it is not surprising that social play is regulated by neurotransmitter systems implicated in reward, including the mesolimbic DA pathway (Trezza et al., 2010; Achterberg et al., 2016; Manduca et al., 2016). Novelty seeking is also regulated by reward-related circuits and mesolimbic DA (Hooks and Kalivas, 1995; Rebec et al., 1997; Wingo et al., 2016). Both social play and novelty seeking peak in juveniles/early adolescents and then decline thereafter (Panksepp, 1981; Pellis and Pellis, 1990; Douglas et al., 2003; Stansfield and Kirstein, 2006; Vetter-O'Hagen and Spear, 2012a). Siberian hamsters also exhibit the same periadolescent declines in social play and novelty seeking when reared in an LD photoperiod that triggers rapid pubertal development (M. J. Paul, C. K. Probst, L. M. Brown, and G. J. de Vries, unpublished data; R. F. Kyne, Q. E. Carroll, K. C. Schatz, R. Y. Bivieca, and M. J. Paul, unpublished data). When puberty is delayed by $\mathrm{SD}$ rearing, the decline in play is completed before pubertal onset and the development of play is dissociated from puberty. The decline in novelty seeking, however, is delayed in SD-reared Siberian hamsters and remains coincident with puberty. These data suggest that the development of play is puberty-independent, whereas that of novelty seeking is puberty-dependent. While further research is necessary, this model provides a novel and exciting approach to disentangle puberty-dependent and pubertyindependent influences on adolescent behavioral and neural development.

\section{Emerging themes}

The factors contributing to adolescent reward are many, and we are only beginning to understand the complex interactions between neural networks, endocrine axes, and environmental cues that direct the development of a functioning male- and femaletypical mesocorticolimbic reward circuit. The many behavioral changes and neuroendocrine interactions may seem chaotic, but it is clear that adolescent development is a highly regulated and coordinated process. In this review, we have highlighted a few overarching themes that are beginning to emerge from the chaos: (1) There are notable sex differences in adolescent development that might underlie sexually dimorphic reward-associated behaviors in adulthood. (2) The mesocorticolimbic pathway is critical for adolescent changes in social reward and reward learning. (3) Reorganization of the reward circuitry, particularly the PFC, during adolescence relies on social interactions, pubertal hormones, as well as nonpubertal processes. (4) Adolescent reward circuitry is highly vulnerable to social stress and drugs of abuse. Further research is necessary for a comprehensive understanding of the factors that regulate development of the mesocorticolimbic pathway, those that lead to increased vulnerability to disruption, and how this process drives developmental changes in motivation and reward. This research would benefit from the use of multiple approaches and models to disentangle the neural, endocrine, and environmental influences on adolescent reward. Together, these investigations will provide valuable insight into sex-specific psychiatric and behavioral disorders that arise during adolescence and could lead to novel avenues for treatment and prevention.

\section{References}

Achterberg EJ, van Kerkhof LW, Damsteegt R, Trezza V, Vanderschuren LJ (2015) Methylphenidate and atomoxetine inhibit social play behavior through prefrontal and subcortical limbic mechanisms in rats. J Neurosci 35:161-169. CrossRef Medline

Achterberg EJ, van Kerkhof LW, Servadio M, van Swieten MM, Houwing DJ, Aalderink M, Driel NV, Trezza V, Vanderschuren LJ (2016) Contrasting roles of dopamine and noradrenaline in the motivational properties of social play behavior in rats. Neuropsychopharmacology 41:858-868. CrossRef Medline

Albertin SV, Mulder AB, Tabuchi E, Zugaro MB, Wiener SI (2000) Lesions of the medial shell of the nucleus accumbens impair rats in finding larger rewards, but spare reward-seeking behavior. Behav Brain Res 117:173183. CrossRef Medline

Andersen SL, Thompson AT, Rutstein M, Hostetter JC, Teicher MH (2000) Dopamine receptor pruning in prefrontal cortex during the periadolescent period in rats. Synapse 37:167-169. CrossRef Medline

Andrews WW, Ojeda SR (1981) A quantitative analysis of the maturation of steroid negative feedbacks controlling gonadotropin release in the female rat: the infantile-juvenile periods, transition from an androgenic to a predominantly estrogenic control. Endocrinology 108:1313-1320. CrossRef Medline

Andrzejewski ME, Schochet TL, Feit EC, Harris R, McKee BL, Kelley AE (2011) A comparison of adult and adolescent rat behavior in operant learning, extinction, and behavioral inhibition paradigms. Behav Neurosci 125:93-105. CrossRef Medline 
Anker JJ, Carroll ME (2010) Reinstatement of cocaine seeking induced by drugs, cues, and stress in adolescent and adult rats. Psychopharmacology (Berl) 208:211-222. CrossRef Medline

Arakawa $\mathrm{H}$ (2003) The effects of isolation rearing on open-field behavior in male rats depends on developmental stages. Dev Psychobiol 43:11-19. CrossRef Medline

Arnold AP (2017) A general theory of sexual differentiation. J Neurosci Res 95:291-300. CrossRef Medline

Arruda-Carvalho M, Wu WC, Cummings KA, Clem RL (2017) Optogenetic examination of prefrontal-amygdala synaptic development. J Neurosci 37:2976-2985. CrossRef Medline

Ashby DM, Habib D, Dringenberg HC, Reynolds JN, Beninger RJ (2010) Subchronic MK-801 treatment and post-weaning social isolation in rats: differential effects on locomotor activity and hippocampal long-term potentiation. Behav Brain Res 212:64-70. CrossRef Medline

Baarendse PJ, Counotte DS, O’Donnell P, Vanderschuren LJ (2013) Early social experience is critical for the development of cognitive control and dopamine modulation of prefrontal cortex function. Neuropsychopharmacology 38:1485-1494. CrossRef Medline

Bagot RC, Parise EM, Peña CJ, Zhang HX, Maze I, Chaudhury D, Persaud B, Cachope R, Bolaños-Guzman CA, Cheer J, Deisseroth K, Han MH, Nestler EJ (2015) Ventral hippocampal afferents to the nucleus accumbens regulate susceptibility to depression. Nat Commun 6:7062. CrossRef Medline

Becker JB (2009) Sexual differentiation of motivation: a novel mechanism? Horm Behav 55:646-654. CrossRef Medline

Becker JB, Perry AN, Westenbroek C (2012) Sex differences in the neural mechanisms mediating addiction: a new synthesis and hypothesis. Biol Sex Differ 3:14. CrossRef Medline

Bell MR, Sisk CL (2013) Dopamine mediates testosterone-induced social reward in male Syrian hamsters. Endocrinology 154:1225-1234. CrossRef Medline

Bell MR, Meerts SH, Sisk CL (2010) Male Syrian hamsters demonstrate a conditioned place preference for sexual behavior and female chemosensory stimuli. Horm Behav 58:410-414. CrossRef Medline

Bell MR, Meerts SH, Sisk CL (2013a) Adolescent brain maturation is necessary for adult-typical mesocorticolimbic responses to a rewarding social cue. Dev Neurobiol 73:856-869. CrossRef Medline

Bell MR, De Lorme KC, Figueira RJ, Kashy DA, Sisk CL (2013b) Adolescent gain in positive valence of a socially relevant stimulus: engagement of the mesocorticolimbic reward circuitry. Eur J Neurosci 37:457-468. CrossRef Medline

Benes FM, Taylor JB, Cunningham MC (2000) Convergence and plasticity of monoaminergic systems in the medial prefrontal cortex during the postnatal period: implications for the development of psychopathology. Cereb Cortex 10:1014-1027. CrossRef Medline

Bittman EL, Jetton AE, Villalba C, Devries GJ (1996) Effects of photoperiod and androgen on pituitary function and neuropeptide staining in Siberian hamsters. Am J Physiol 271:R64-R72. Medline

Bouwmeester H, Smits K, Van Ree JM (2002a) Neonatal development of projections to the basolateral amygdala from prefrontal and thalamic structures in rat. J Comp Neurol 450:241-255. CrossRef Medline

Bouwmeester H, Wolterink G, van Ree JM (2002b) Neonatal development of projections from the basolateral amygdala to prefrontal, striatal, and thalamic structures in the rat. J Comp Neurol 442:239-249. CrossRef Medline

Brenes JC, Fornaguera J (2008) Effects of environmental enrichment and social isolation on sucrose consumption and preference: associations with depressive-like behavior and ventral striatum dopamine. Neurosci Lett 436:278-282. CrossRef Medline

Brenes JC, Rodríguez O, Fornaguera J (2008) Differential effect of environment enrichment and social isolation on depressive-like behavior, spontaneous activity and serotonin and norepinephrine concentration in prefrontal cortex and ventral striatum. Pharmacol Biochem Behav 89:8593. CrossRef Medline

Brenhouse HC, Sonntag KC, Andersen SL (2008) Transient D1 dopamine receptor expression on prefrontal cortex projection neurons: relationship to enhanced motivational salience of drug cues in adolescence. J Neurosci 28:2375-2382. CrossRef Medline

Burke AR, McCormick CM, Pellis SM, Lukkes JL (2017) Impact of adolescent social experiences on behavior and neural circuits implicated in mental illnesses. Neurosci Biobehav Rev 76:280-300. CrossRef Medline
Burnett S, Bault N, Coricelli G, Blakemore SJ (2010) Adolescents' heightened risk-seeking in a probabilistic gambling task. Cogn Dev 25:183-196. CrossRef Medline

Burton CL, Fletcher PJ (2012) Age and sex differences in impulsive action in rats: the role of dopamine and glutamate. Behav Brain Res 230:21-33. CrossRef Medline

Caballero A, Thomases DR, Flores-Barrera E, Cass DK, Tseng KY (2014) Emergence of GABAergic-dependent regulation of input-specific plasticity in the adult rat prefrontal cortex during adolescence. Psychopharmacology (Berl) 231:1789-1796. CrossRef Medline

Calcagnetti DJ, Schechter MD (1992) Place conditioning reveals the rewarding aspect of social interaction in juvenile rats. Physiol Behav 51: 667-672. CrossRef Medline

Chappell AM, Carter E, McCool BA, Weiner JL (2013) Adolescent rearing conditions influence the relationship between initial anxiety-like behavior and ethanol drinking in male Long Evans rats. Alcohol Clin Exp Res 37 [Suppl 1]:E394-E403.

Chen CY, Storr CL, Anthony JC (2009) Early-onset drug use and risk for drug dependence problems. Addict Behav 34:319-322. CrossRef Medline

Collado A, Felton JW, MacPherson L, Lejuez CW (2014) Longitudinal trajectories of sensation seeking, risk taking propensity, and impulsivity across early to middle adolescence. Addict Behav 39:1580-1588. CrossRef Medline

Compton WM, Thomas YF, Stinson FS, Grant BF (2007) Prevalence, correlates, disability, and comorbidity of DSM-IV drug abuse and dependence in the United States: results from the national epidemiologic survey on alcohol and related conditions. Arch Gen Psychiatry 64:566-576. CrossRef Medline

Cooke BM, Chowanadisai W, Breedlove SM (2000) Post-weaning social isolation of male rats reduces the volume of the medial amygdala and leads to deficits in adult sexual behavior. Behav Brain Res 117:107-113. CrossRef Medline

Covington HE 3rd, Lobo MK, Maze I, Vialou V, Hyman JM, Zaman S, LaPlant Q, Mouzon E, Ghose S, Tamminga CA, Neve RL, Deisseroth K, Nestler EJ (2010) Antidepressant effect of optogenetic stimulation of the medial prefrontal cortex. J Neurosci 30:16082-16090. CrossRef Medline

Coyle JT, Molliver ME (1977) Major innervation of newborn rat cortex by monoaminergic neurons. Science 196:444-447. CrossRef Medline

Cunningham MG, Bhattacharyya S, Benes FM (2002) Amygdalo-cortical sprouting continues into early adulthood: implications for the development of normal and abnormal function during adolescence. J Comp Neurol 453:116-130. CrossRef Medline

Currie CL, Wild TC (2012) Adolescent use of prescription drugs to get high in Canada. Can J Psychiatry 57:745-751. CrossRef Medline

Cyrenne DL, Brown GR (2011) Effects of suppressing gonadal hormones on response to novel objects in adolescent rats. Horm Behav 60:625-631. CrossRef Medline

Degenhardt L, Coffey C, Carlin JB, Moran P, Patton GC (2007) Who are the new amphetamine users? A 10-year prospective study of young Australians. Addiction 102:1269-1279. CrossRef Medline

De Lorme KC, Schulz KM, Salas-Ramirez KY, Sisk CL (2012) Pubertal testosterone organizes regional volume and neuronal number within the medial amygdala of adult male Syrian hamsters. Brain Res 1460:33-40. CrossRef Medline

Diamond A (2002) Normal development of prefrontal cortex from birth to young adulthood: cognitive functions, anatomy, and biochemistry. In: Principles of frontal lobe function, Ed 2 (Stuss D KR, ed), pp 466-503. Oxford: Oxford UP.

Döhler KD, Wuttke W (1975) Changes with age in levels of serum gonadotropins, prolactin and gonadal steroids in prepubertal male and female rats. Endocrinology 97:898-907. CrossRef Medline

Donner NC, Johnson PL, Fitz SD, Kellen KE, Shekhar A, Lowry CA (2012) Elevated tph2 mRNA expression in a rat model of chronic anxiety. Depress Anxiety 29:307-319. CrossRef Medline

Doremus TL, Brunell SC, Rajendran P, Spear LP (2005) Factors influencing elevated ethanol consumption in adolescent relative to adult rats. Alcohol Clin Exp Res 29:1796-1808. CrossRef Medline

Doremus-Fitzwater TL, Spear LP (2016) Reward-centricity and attenuated aversions: an adolescent phenotype emerging from studies in laboratory animals. Neurosci Biobehav Rev 70:121-134. CrossRef Medline

Dosenbach NU, Nardos B, Cohen AL, Fair DA, Power JD, Church JA, Nelson SM, Wig GS, Vogel AC, Lessov-Schlaggar CN, Barnes KA, Dubis JW, 
Feczko E, Coalson RS, Pruett JR Jr, Barch DM, Petersen SE, Schlaggar BL (2010) Prediction of individual brain maturity using fMRI. Science 329: 1358-1361. CrossRef Medline

Douglas LA, Varlinskaya EI, Spear LP (2003) Novel-object place conditioning in adolescent and adult male and female rats: effects of social isolation. Physiol Behav 80:317-325. CrossRef Medline

Douglas LA, Varlinskaya EI, Spear LP (2004) Rewarding properties of social interactions in adolescent and adult male and female rats: impact of social versus isolate housing of subjects and partners. Dev Psychobiol 45:153162. CrossRef Medline

Drzewiecki CM, Willing J, Juraska JM (2016) Synaptic number changes in the medial prefrontal cortex across adolescence in male and female rats: a role for pubertal onset. Synapse 70:361-368. CrossRef Medline

Dubois SL, Wolfe A, Radovick S, Boehm U, Levine JE (2016) Estradiol restrains prepubertal gonadotropin secretion in female mice via activation of ERalpha in kisspeptin neurons. Endocrinology 157:1546-1554. CrossRef Medline

Edmonds KE, Stetson MH (1993) Effect of photoperiod on gonadal maintenance and development in the marsh rice rat (Oryzomys palustris). Gen Comp Endocrinol 92:281-291. CrossRef Medline

Einon DF, Morgan MJ (1977) A critical period for social isolation in the rat. Dev Psychobiol 10:123-132. CrossRef Medline

Elgar FJ, Phillips N, Hammond N (2011) Trends in alcohol and drug use among Canadian adolescents, 1990-2006. Can J Psychiatry 56:243-247. CrossRef Medline

Espejo EP, Hammen CL, Connolly NP, Brennan PA, Najman JM, Bor W (2007) Stress sensitization and adolescent depressive severity as a function of childhood adversity: a link to anxiety disorders. J Abnorm Child Psychol 35:287-299. CrossRef Medline

Fabricius K, Helboe L, Fink-Jensen A, Wortwein G, Steiniger-Brach B (2011) Pharmacological characterization of social isolation-induced hyperactivity. Psychopharmacology (Berl) 215:257-266. CrossRef Medline

Farrell MR, Holland FH, Shansky RM, Brenhouse HC (2016) Sex-specific effects of early life stress on social interaction and prefrontal cortex dendritic morphology in young rats. Behav Brain Res 310:119-125. CrossRef Medline

Felix-Ortiz AC, Burgos-Robles A, Bhagat ND, Leppla CA, Tye KM (2016) Bidirectional modulation of anxiety-related and social behaviors by amygdala projections to the medial prefrontal cortex. Neuroscience 321: 197-209. CrossRef Medline

Fombonne E (2009) Epidemiology of pervasive developmental disorders. Pediatr Res 65:591-598. CrossRef Medline

Friemel CM, Spanagel R, Schneider M (2010) Reward sensitivity for a palatable food reward peaks during pubertal developmental in rats. Front Behav Neurosci 4:39. CrossRef Medline

Fulford AJ, Marsden CA (1998a) Effect of isolation rearing on conditioned dopamine release in vivo in the nucleus accumbens of the rat. J Neurochem 70:384-390. CrossRef Medline

Fulford AJ, Marsden CA (1998b) Conditioned release of 5-hydroxytryptamine in vivo in the nucleus accumbens following isolation rearing in the rat. Neuroscience 83:481-487. CrossRef Medline

Gopnik A, O'Grady S, Lucas CG, Griffiths TL, Wente A, Bridgers S, Aboody R, Fung H, Dahl RE (2017) Changes in cognitive flexibility and hypothesis search across human life history from childhood to adolescence to adulthood. Proc Natl Acad Sci U S A. Advance online publication. Retrieved Jul. 24, 2017. doi: 10.1073/pnas.1700811114. CrossRef Medline

Graber JA (2013) Pubertal timing and the development of psychopathology in adolescence and beyond. Horm Behav 64:262-269. CrossRef Medline

Grant BF (1997) Prevalence and correlates of alcohol use and DSM-IV alcohol dependence in the United States: results of the National Longitudinal Alcohol Epidemiologic Survey. J Stud Alcohol 58:464-473. CrossRef Medline

Grant BF, Dawson DA (1998) Age of onset of drug use and its association with DSM-IV drug abuse and dependence: results from the National Longitudinal Alcohol Epidemiologic Survey. J Subst Abuse 10:163-173. CrossRef Medline

Hamel L, Thangarasa T, Samadi O, Ito R (2017) Caudal nucleus accumbens core is critical in the regulation of cue-elicited approach-avoidance decisions. eNeuro 4:ENEURO.0330-16.2017. CrossRef Medline

Hammerslag LR, Gulley JM (2014) Age and sex differences in reward behavior in adolescent and adult rats. Dev Psychobiol 56:611-621. CrossRef Medline
Hammerslag LR, Waldman AJ, Gulley JM (2014) Effects of amphetamine exposure in adolescence or young adulthood on inhibitory control in adult male and female rats. Behav Brain Res 263:22-33. CrossRef Medline

Hankin BL, Abramson LY, Moffitt TE, Silva PA, McGee R, Angell KE (1998) Development of depression from preadolescence to young adulthood: emerging gender differences in a 10-year longitudinal study. J Abnorm Psychol 107:128-140. CrossRef Medline

Hankosky ER, Kofsky NM, Gulley JM (2013) Age of exposure-dependent effects of amphetamine on behavioral flexibility. Behav Brain Res 252: 117-125. CrossRef Medline

Hasin DS, Stinson FS, Ogburn E, Grant BF (2007) Prevalence, correlates, disability, and comorbidity of DSM-IV alcohol abuse and dependence in the United States: results from the National Epidemiologic Survey on Alcohol and Related Conditions. Arch Gen Psychiatry 64:830-842. CrossRef Medline

Heim C, Newport DJ, Mletzko T, Miller AH, Nemeroff CB (2008) The link between childhood trauma and depression: insights from HPA axis studies in humans. Psychoneuroendocrinology 33:693-710. CrossRef Medline

Herting MM, Gautam P, Spielberg JM, Kan E, Dahl RE, Sowell ER (2014) The role of testosterone and estradiol in brain volume changes across adolescence: a longitudinal structural MRI study. Hum Brain Mapp 35: 5633-5645. CrossRef Medline

Herting MM, Kim R, Uban KA, Kan E, Binley A, Sowell ER (2017) Longitudinal changes in pubertal maturation and white matter microstructure. Psychoneuroendocrinology 81:70-79. CrossRef Medline

Hickey AJ, Reynolds JN, Beninger RJ (2012) Post-weaning social isolation and subchronic NMDA glutamate receptor blockade: effects on locomotor activity and GABA signaling in the rat suggest independent mechanisms. Pharmacol Biochem Behav 101:231-238. CrossRef Medline

Hines M, Allen LS, Gorski RA (1992) Sex differences in subregions of the medial nucleus of the amygdala and the bed nucleus of the stria terminalis of the rat. Brain Res 579:321-326. CrossRef Medline

Hoffmann K (1978) Effects of short photoperiods on puberty, growth and moult in the Djungarian hamster (Phodopus sungorus). J Reprod Fertil 54:29-35. CrossRef Medline

Holder MK, Blaustein JD (2017) Developmental time course and effects of immunostressors that alter hormone-responsive behavior on microglia in the peripubertal and adult female mouse brain. PLoS One 12:e0171381. CrossRef Medline

Holtzman CW, Trotman HD, Goulding SM, Ryan AT, Macdonald AN, Shapiro DI, Brasfield JL, Walker EF (2013) Stress and neurodevelopmental processes in the emergence of psychosis. Neuroscience 249:172-191. CrossRef Medline

Hooks MS, Kalivas PW (1995) The role of mesoaccumbens-pallidal circuitry in novelty-induced behavioral activation. Neuroscience 64:587597. CrossRef Medline

Howes SR, Dalley JW, Morrison CH, Robbins TW, Everitt BJ (2000) Leftward shift in the acquisition of cocaine self-administration in isolationreared rats: relationship to extracellular levels of dopamine, serotonin and glutamate in the nucleus accumbens and amygdala-striatal FOS expression. Psychopharmacology (Berl) 151:55-63. CrossRef Medline

Ismail N, Blaustein JD (2013) Pubertal immune challenge blocks the ability of estradiol to enhance performance on cognitive tasks in adult female mice. Psychoneuroendocrinology 38:1170-1177. CrossRef Medline

Ismail N, Kumlin AM, Blaustein JD (2013) A pubertal immune challenge alters the antidepressant-like effects of chronic estradiol treatment in inbred and outbred adult female mice. Neuroscience 249:43-52. CrossRef Medline

Jessen HM, Kolodkin MH, Bychowski ME, Auger CJ, Auger AP (2010) The nuclear receptor corepressor has organizational effects within the developing amygdala on juvenile social play and anxiety-like behavior. Endocrinology 151:1212-1220. CrossRef Medline

Johnston RE (1986) Effects of female odors on the sexual behavior of male hamsters. Behav Neural Biol 46:168-188. CrossRef Medline

Johnston RE, Coplin B (1979) Development of responses to vaginal secretion and other substances in golden hamsters. Behav Neural Biol 25:473489. CrossRef Medline

Kalsbeek A, Voorn P, Buijs RM, Pool CW, Uylings HB (1988) Development of the dopaminergic innervation in the prefrontal cortex of the rat. J Comp Neurol 269:58-72. CrossRef Medline

Kanit L, Taskiran D, Yilmaz OA, Balkan B, Demirgören S, Furedy JJ, Pögün S 
(2000) Sexually dimorphic cognitive style in rats emerges after puberty. Brain Res Bull 52:243-248. CrossRef Medline

Kavaliers M, Choleris E (2001) Antipredator responses and defensive behavior: ecological and ethological approaches for the neurosciences. Neurosci Biobehav Rev 25:577-586. CrossRef Medline

Kerchner M, Malsbury CW, Ward OB, Ward IL (1995) Sexually dimorphic areas in the rat medial amygdala: resistance to the demasculinizing effect of prenatal stress. Brain Res 672:251-260. CrossRef Medline

Kessler RC, Berglund P, Demler O, Jin R, Merikangas KR, Walters EE (2005) Lifetime prevalence and age-of-onset distributions of DSM-IV disorders in the National Comorbidity Survey Replication. Arch Gen Psychiatry 62:593-602. CrossRef Medline

Knapska E, Radwanska K, Werka T, Kaczmarek L (2007) Functional internal complexity of amygdala: focus on gene activity mapping after behavioral training and drugs of abuse. Physiol Rev 87:1113-1173. CrossRef Medline

Koss WA, Belden CE, Hristov AD, Juraska JM (2014) Dendritic remodeling in the adolescent medial prefrontal cortex and the basolateral amygdala of male and female rats. Synapse 68:61-72. CrossRef Medline

Koss WA, Lloyd MM, Sadowski RN, Wise LM, Juraska JM (2015) Gonadectomy before puberty increases the number of neurons and glia in the medial prefrontal cortex of female, but not male, rats. Dev Psychobiol 57:305-312. CrossRef Medline

Kuhn C, Johnson M, Thomae A, Luo B, Simon SA, Zhou G, Walker QD (2010) The emergence of gonadal hormone influences on dopaminergic function during puberty. Horm Behav 58:122-137. CrossRef Medline

Kuzmin A, Johansson B (1999) Expression of c-fos, NGFI-A and secretogranin II mRNA in brain regions during initiation of cocaine selfadministration in mice. Eur J Neurosci 11:3694-3700. CrossRef Medline

Ladd GW, Ettekal I, Kochenderfer-Ladd B, Rudolph KD, Andrews RK (2014) Relations among chronic peer group rejection, maladaptive behavioral dispositions, and early adolescents' peer perceptions. Child Dev 85:971-988. CrossRef Medline

Lambe EK, Krimer LS, Goldman-Rakic PS (2000) Differential postnatal development of catecholamine and serotonin inputs to identified neurons in prefrontal cortex of rhesus monkey. J Neurosci 20:8780-8787. Medline

Larson RW, Richards MH, Moneta G, Holmbeck G, Duckett E (1996) Changes in adolescents' daily interactions with their families from ages 10 to 18: disengagement and transformation. Dev Psychol 32:744-754. CrossRef

Lawson Handley LJ, Perrin N (2007) Advances in our understanding of mammalian sex-biased dispersal. Mol Ecol 16:1559-1578. CrossRef Medline

Leatherdale ST, Burkhalter R (2012) The substance use profile of Canadian youth: exploring the prevalence of alcohol, drug and tobacco use by gender and grade. Addict Behav 37:318-322. CrossRef Medline

Lee H, Sawatari A (2011) Medium spiny neurons of the neostriatal matrix exhibit specific, stereotyped changes in dendritic arborization during a critical developmental period in mice. Eur J Neurosci 34:1345-1354. CrossRef Medline

Levin ED, Lawrence SS, Petro A, Horton K, Rezvani AH, Seidler FJ, Slotkin TA (2007) Adolescent vs adult-onset nicotine self-administration in male rats: duration of effect and differential nicotinic receptor correlates. Neurotoxicol Teratol 29:458-465. CrossRef Medline

Levitt P, Moore RY (1979) Development of the noradrenergic innervation of neocortex. Brain Res 162:243-259. CrossRef Medline

Lidov HG, Grzanna R, Molliver ME (1980) The serotonin innervation of the cerebral cortex in the rat: an immunohistochemical analysis. Neuroscience 5:207-227. CrossRef Medline

Lipari R, Jean-Francois B (2013) Trends in perception of risk and availability of substance use among full-time college students. The CBHSQ Report: August 16, 2016. Rockville, MD: Center for Behavioral Health Statistics and Quality, Substance Abuse and Mental Health Services Administration.

Luciana M (2013) Adolescent brain development in normality and psychopathology. Dev Psychopathol 25:1325-1345. CrossRef Medline

Lukkes JL, Forster GL, Renner KJ, Summers CH (2008) Corticotropinreleasing factor 1 and 2 receptors in the dorsal raphe differentially affect serotonin release in the nucleus accumbens. Eur J Pharmacol 578:185193. CrossRef Medline

Lukkes JL, Mokin MV, Scholl JL, Forster GL (2009a) Adult rats exposed to early-life social isolation exhibit increased anxiety and conditioned fear behavior, and altered hormonal stress responses. Horm Behav 55:248256. CrossRef Medline

Lukkes JL, Watt MJ, Lowry CA, Forster GL (2009b) Consequences of postweaning social isolation on anxiety behavior and related neural circuits in rodents. Front Behav Neurosci 3:18. CrossRef Medline

Lukkes JL, Summers CH, Scholl JL, Renner KJ, Forster GL (2009c) Early life social isolation alters corticotropin-releasing factor responses in adult rats. Neuroscience 158:845-855. CrossRef Medline

Lukkes JL, Kopelman JM, Donner NC, Hale MW, Lowry CA (2013) Development $\times$ environment interactions control tph2 mRNA expression. Neuroscience 237:139-150. CrossRef Medline

MacAskill AF, Cassel JM, Carter AG (2014) Cocaine exposure reorganizes cell type- and input-specific connectivity in the nucleus accumbens. Nat Neurosci 17:1198-1207. CrossRef Medline

Manduca A, Servadio M, Damsteegt R, Campolongo P, Vanderschuren LJ, Trezza V (2016) Dopaminergic neurotransmission in the nucleus accumbens modulates social play behavior in rats. Neuropsychopharmacology 41:2215-2223. CrossRef Medline

Manitt C, Mimee A, Eng C, Pokinko M, Stroh T, Cooper HM, Kolb B, Flores C (2011) The netrin receptor DCC is required in the pubertal organization of mesocortical dopamine circuitry. J Neurosci 31:8381-8394. CrossRef Medline

Manitt C, Eng C, Pokinko M, Ryan RT, Torres-Berrió A, Lopez JP, Yogendran SV, Daubaras MJ, Grant A, Schmidt ER, Tronche F, Krimpenfort P, Cooper HM, Pasterkamp RJ, Kolb B, Turecki G, Wong TP, Nestler EJ, Giros B, Flores C (2013) dcc orchestrates the development of the prefrontal cortex during adolescence and is altered in psychiatric patients. Transl Psychiatry 3:e338. CrossRef Medline

Markham JA, Morris JR, Juraska JM (2007) Neuron number decreases in the rat ventral, but not dorsal, medial prefrontal cortex between adolescence and adulthood. Neuroscience 144:961-968. CrossRef Medline

Marshall AT, Liu AT, Murphy NP, Maidment NT, Ostlund SB (2017) Sexspecific enhancement of palatability-driven feeding in adolescent rats. PLoS One 12:e0180907. CrossRef Medline

McCabe SE, West BT, Morales M, Cranford JA, Boyd CJ (2007) Does early onset of non-medical use of prescription drugs predict subsequent prescription drug abuse and dependence? Results from a national study. Addiction 102:1920-1930. CrossRef Medline

McGinty VB, Grace AA (2009) Timing-dependent regulation of evoked spiking in nucleus accumbens neurons by integration of limbic and prefrontal cortical inputs. J Neurophysiol 101:1823-1835. CrossRef Medline

Meaney MJ, McEwen BS (1986) Testosterone implants into the amygdala during the neonatal period masculinize the social play of juvenile female rats. Brain Res 398:324-328. CrossRef Medline

Meaney MJ, Dodge AM, Beatty WW (1981) Sex-dependent effects of amygdaloid lesions on the social play of prepubertal rats. Physiol Behav 26:467472. CrossRef Medline

Meijs-Roelofs HM, Kramer P (1979) Maturation of the inhibitory feedback action of oestrogen on follicle-stimulating hormone secretion in the immature female rat: a role for alpha-foetoprotein. J Endocrinol 81:199208. CrossRef Medline

Miniño A (2010) Mortality among teenagers aged 12-19 years: United States, 1999-2006. NCHS Data Brief 1-8.

Morrison SE, McGinty VB, du Hoffmann J, Nicola SM (2017) Limbicmotor integration by neural excitations and inhibitions in the nucleus accumbens. J Neurophysiol. Advance online publication. Retrieved Aug. 9, 2017. doi: 10.1152/jn.00465.2017. CrossRef Medline

Murphy MR, Schneider GE (1970) Olfactory bulb removal eliminates mating behavior in the male golden hamster. Science 167:302-304. CrossRef Medline

Naneix F, Marchand AR, Di Scala G, Pape JR, Coutureau E (2012) Parallel maturation of goal-directed behavior and dopaminergic systems during adolescence. J Neurosci 32:16223-16232. CrossRef Medline

Nelson RJ, Marinovic AC, Moffatt CA, Kriegsfeld LJ, Kim S (1997) The effects of photoperiod and food intake on reproductive development in male deer mice (Peromyscus maniculatus). Physiol Behav 62:945-950. CrossRef Medline

Ojeda SR, Terasawa E (2002) Neuroendocrine regulation of puberty. In: Hormones, brain and behavior (Pfaff DW, Etgen AM, Fahrbach SE, Rubin RT, eds), pp 589-659. San Diego: Academic.

Paine TA, Swedlow N, Swetschinski L (2017) Decreasing GABA function 
within the medial prefrontal cortex or basolateral amygdala decreases sociability. Behav Brain Res 317:542-552. CrossRef Medline

Palmer RH, Young SE, Hopfer CJ, Corley RP, Stallings MC, Crowley TJ, Hewitt JK (2009) Developmental epidemiology of drug use and abuse in adolescence and young adulthood: evidence of generalized risk. Drug Alcohol Depend 102:78-87. CrossRef Medline

Panksepp J (1981) The ontogeny of play in rats. Dev Psychobiol 14:327-332. CrossRef Medline

Patterson TL, Smith LW, Smith TL, Yager J, Grant I (1992) Symptoms of illness in late adulthood are related to childhood social deprivation and misfortune in men but not in women. J Behav Med 15:113-125. CrossRef Medline

Pattwell SS, Liston C, Jing D, Ninan I, Yang RR, Witztum J, Murdock MH, Dincheva I, Bath KG, Casey BJ, Deisseroth K, Lee FS (2016) Dynamic changes in neural circuitry during adolescence are associated with persistent attenuation of fear memories. Nat Commun 7:11475. CrossRef Medline

Paul MJ, Park JH, Horton TH, Alvarez MI, Burke MK, Place NJ, Zucker I (2006) Photoperiodic regulation of compensatory testicular hypertrophy in hamsters. Biol Reprod 75:261-269. CrossRef Medline

Paul MJ, Zucker I, Schwartz WJ (2008) Tracking the seasons: the internal calendars of vertebrates. Philos Trans R Soc Lond B Biol Sci 363:341-361. CrossRef Medline

Pellegrini AD (1988) Elementary-school children's rough-and-tumble play and social competence. Dev Psychol 24:802-806. CrossRef

Pellis SM, Pellis VC (1990) Differential rates of attack, defense, and counterattack during the developmental decrease in play fighting by male and female rats. Dev Psychobiol 23:215-231. CrossRef Medline

Pellis SM, Pellis VC (2017) What is play fighting and what is it good for? Learn Behav. Advance online publication. Retrieved Apr. 3, 2017. doi: 10.3758/s13420-017-0264-3. CrossRef Medline

Peters YM, O’Donnell P (2005) Social isolation rearing affects prefrontal cortical response to ventral tegmental area stimulation. Biol Psychiatry 57:1205-1208. CrossRef Medline

Piekarski DJ, Boivin JR, Wilbrecht L (2017) Ovarian hormones organize the maturation of inhibitory neurotransmission in the frontal cortex at puberty onset in female mice. Curr Biol 27:1735-1745.e3. CrossRef Medline

Pokinko M, Grant A, Shahabi F, Dumont Y, Manitt C, Flores C (2017) Dcc haploinsufficiency regulates dopamine receptor expression across postnatal lifespan. Neuroscience 346:182-189. CrossRef Medline

Primus RJ, Kellogg CK (1989) Pubertal-related changes influence the development of environment-related social interaction in the male rat. Dev Psychobiol 22:633-643. CrossRef Medline

Primus RJ, Kellogg CK (1990) Developmental influence of gonadal function on the anxiolytic effect of diazepam on environment-related social interaction in the male rat. Behav Pharmacol 1:437-446. Medline

Pritchard LM, Hensleigh E, Lynch S (2012) Altered locomotor and stereotyped responses to acute methamphetamine in adolescent, maternally separated rats. Psychopharmacology (Berl) 223:27-35. CrossRef Medline

Qu Y, Galvan A, Fuligni AJ, Lieberman MD, Telzer EH (2015) Longitudinal changes in prefrontal cortex activation underlie declines in adolescent risk taking. J Neurosci 35:11308-11314. CrossRef Medline

Raznahan A, Lee Y, Stidd R, Long R, Greenstein D, Clasen L, Addington A, Gogtay N, Rapoport JL, Giedd JN (2010) Longitudinally mapping the influence of sex and androgen signaling on the dynamics of human cortical maturation in adolescence. Proc Natl Acad Sci U S A 107:1698816993. CrossRef Medline

Raznahan A, Shaw PW, Lerch JP, Clasen LS, Greenstein D, Berman R, Pipitone J, Chakravarty MM, Giedd JN (2014) Longitudinal four-dimensional mapping of subcortical anatomy in human development. Proc Natl Acad Sci U S A 111:1592-1597. CrossRef Medline

Rebec GV, Christensen JR, Guerra C, Bardo MT (1997) Regional and temporal differences in real-time dopamine efflux in the nucleus accumbens during free-choice novelty. Brain Res 776:61-67. CrossRef Medline

Ressler KJ, Mayberg HS (2007) Targeting abnormal neural circuits in mood and anxiety disorders: from the laboratory to the clinic. Nat Neurosci 10:1116-1124. CrossRef Medline

Reynolds LM, Makowski CS, Yogendran SV, Kiessling S, Cermakian N, Flores C (2015) Amphetamine in adolescence disrupts the development of medial prefrontal cortex dopamine connectivity in a DCC-dependent manner. Neuropsychopharmacology 40:1101-1112. CrossRef Medline

Reynolds LM, Pokinko M, Torres-Berrio A, Cuesta S, Lambert LC, Del Cid
Pellitero E, Wodzinski M, Manitt C, Krimpenfort P, Kolb B, Flores C (2017) DCC receptors drive prefrontal cortex maturation by determining dopamine axon targeting in adolescence. Biol Psychiatry. Advance online publication. Retrieved Jun. 16, 2017. doi: 10.1016/j.biopsych.2017. 06.009. CrossRef Medline

Robins LN, Przybeck TR (1985) Age of onset of drug use as a factor in drug and other disorders. NIDA Res Monogr 56:178-192. Medline

Romeo RD, Parfitt DB, Richardson HN, Sisk CL (1998) Pheromones elicit equivalent levels of Fos-immunoreactivity in prepubertal and adult male Syrian hamsters. Horm Behav 34:48-55. CrossRef Medline

Rosenberg DR, Lewis DA (1994) Changes in the dopaminergic innervation of monkey prefrontal cortex during late postnatal development: a tyrosine hydroxylase immunohistochemical study. Biol Psychiatry 36:272277. CrossRef Medline

Sadleir RMFS (1969) The ecology of reproduction in wild and domestic mammals. London: Methuen.

Sajdyk TJ, Shekhar A (1997) Excitatory amino acid receptors in the basolateral amygdala regulate anxiety responses in the social interaction test. Brain Res 764:262-264. CrossRef Medline

Sanders SK, Shekhar A (1995) Regulation of anxiety by GABAA receptors in the rat amygdala. Pharmacol Biochem Behav 52:701-706. CrossRef Medline

Scheller-Gilkey G, Woolwine BJ, Cooper I, Gay O, Moynes KA, Miller AH (2003) Relationship of clinical symptoms and substance use in schizophrenia patients on conventional versus atypical antipsychotics. Am J Drug Alcohol Abuse 29:553-566. CrossRef Medline

Schulz KM, Zehr JL, Salas-Ramirez KY, Sisk CL (2009) Testosterone programs adult social behavior before and during, but not after, adolescence. Endocrinology 150:3690-3698. CrossRef Medline

Sherrill LK, Stanis JJ, Gulley JM (2013) Age-dependent effects of repeated amphetamine exposure on working memory in rats. Behav Brain Res 242:84-94. CrossRef Medline

Shulman EP, Harden KP, Chein JM, Steinberg L (2015) Sex differences in the developmental trajectories of impulse control and sensation-seeking from early adolescence to early adulthood. J Youth Adolesc 44:1-17. CrossRef Medline

Smith JK, Neill JC, Costall B (1997) Post-weaning housing conditions influence the behavioural effects of cocaine and D-amphetamine. Psychopharmacology (Berl) 131:23-33. CrossRef Medline

Smith LK, Field EF, Forgie ML, Pellis SM (1996) Dominance and agerelated changes in the play fighting of intact and post-weaning castrated male rats (Rattus norvegicus). Aggressive Behav 22:215-226. CrossRef

Spear LP (2000) The adolescent brain and age-related behavioral manifestations. Neurosci Biobehav Rev 24:417-463. CrossRef Medline

Stansfield KH, Kirstein CL (2006) Effects of novelty on behavior in the adolescent and adult rat. Dev Psychobiol 48:10-15. CrossRef Medline

Steinberg L (2004) Risk taking in adolescence: what changes, and why? Ann N Y Acad Sci 1021:51-58. CrossRef Medline

Stevenson TJ, Prendergast BJ, Nelson RJ (2017) Mammalian seasonal rhythms: behavior and neuroendocrine substrates. In: Hormones, brain and behavior (Pfaff DW, Joëls M, eds), pp 371-398. Amsterdam: Academic Press.

Swendsen J, Burstein M, Case B, Conway KP, Dierker L, He J, Merikangas KR (2012) Use and abuse of alcohol and illicit drugs in US adolescents: results of the National Comorbidity Survey-Adolescent Supplement. Arch Gen Psychiatry 69:390-398. CrossRef Medline

Tarazi FI, Baldessarini RJ (2000) Comparative postnatal development of dopamine $\mathrm{D}(1), \mathrm{D}(2)$ and $\mathrm{D}(4)$ receptors in rat forebrain. Int J Dev Neurosci 18:29-37. CrossRef Medline

Tepper JM, Sharpe NA, Koós TZ, Trent F (1998) Postnatal development of the rat neostriatum: electrophysiological, light- and electron-microscopic studies. Dev Neurosci 20:125-145. CrossRef Medline

Thapar A, Collishaw S, Pine DS, Thapar AK (2012) Depression in adolescence. Lancet 379:1056-1067. CrossRef Medline

Trezza V, Damsteegt R, Vanderschuren LJ (2009) Conditioned place preference induced by social play behavior: parametrics, extinction, reinstatement and disruption by methylphenidate. Eur Neuropsychopharmacol 19:659-669. CrossRef Medline

Trezza V, Baarendse PJ, Vanderschuren LJ (2010) The pleasures of play: pharmacological insights into social reward mechanisms. Trends Pharmacol Sci 31:463-469. CrossRef Medline

Trezza V, Campolongo P, Vanderschuren LJ (2011) Evaluating the reward- 
ing nature of social interactions in laboratory animals. Dev Cogn Neurosci 1:444-458. CrossRef Medline

Trezza V, Damsteegt R, Manduca A, Petrosino S, Van Kerkhof LW, Pasterkamp RJ, Zhou Y, Campolongo P, Cuomo V, Di Marzo V, Vanderschuren LJ (2012) Endocannabinoids in amygdala and nucleus accumbens mediate social play reward in adolescent rats. J Neurosci 32:14899-14908. CrossRef Medline

Trotman HD, Holtzman CW, Ryan AT, Shapiro DI, MacDonald AN, Goulding SM, Brasfield JL, Walker EF (2013) The development of psychotic disorders in adolescence: a potential role for hormones. Horm Behav 64:411-419. CrossRef Medline

Urošević S, Collins P, Muetzel R, Lim K, Luciana M (2012) Longitudinal changes in behavioral approach system sensitivity and brain structures involved in reward processing during adolescence. Dev Psychol 48:14881500. CrossRef Medline

van den Berg CL, Hol T, Van Ree JM, Spruijt BM, Everts H, Koolhaas JM (1999) Play is indispensable for an adequate development of coping with social challenges in the rat. Dev Psychobiol 34:129-138. CrossRef Medline

Van Eden CG, Uylings HB (1985) Postnatal volumetric development of the prefrontal cortex in the rat. J Comp Neurol 241:268-274. CrossRef Medline

Vanderschuren LJ, Niesink RJ, Van Ree JM (1997) The neurobiology of social play behavior in rats. Neurosci Biobehav Rev 21:309-326. CrossRef Medline

Vetter-O'Hagen CS, Spear LP (2011) The effects of gonadectomy on ageand sex-typical patterns of ethanol consumption in Sprague-Dawley rats. Alcohol Clin Exp Res 35:2039-2049. CrossRef Medline

Vetter-O'Hagen CS, Spear LP (2012a) Hormonal and physical markers of puberty and their relationship to adolescent-typical novelty-directed behavior. Dev Psychobiol 54:523-535. CrossRef Medline

Vetter-O'Hagen CS, Spear LP (2012b) The effects of gonadectomy on sexand age-typical responses to novelty and ethanol-induced social inhibition in adult male and female Sprague-Dawley rats. Behav Brain Res 227:224-232. CrossRef Medline

Vialou V, Bagot RC, Cahill ME, Ferguson D, Robison AJ, Dietz DM, Fallon B, Mazei-Robison M, Ku SM, Harrigan E, Winstanley CA, Joshi T, Feng J, Berton O, Nestler EJ (2014) Prefrontal cortical circuit for depressionand anxiety-related behaviors mediated by cholecystokinin: role of DeltaFosB. J Neurosci 34:3878-3887. CrossRef Medline

Volkow ND, Fowler JS, Wang GJ, Telang F, Logan J, Jayne M, Ma Y, Pradhan $\mathrm{K}$, Wong C, Swanson JM (2010) Cognitive control of drug craving inhibits brain reward regions in cocaine abusers. Neuroimage 49:25362543. CrossRef Medline

Warner LA, Kessler RC, Hughes M, Anthony JC, Nelson CB (1995) Prevalence and correlates of drug use and dependence in the United States: results from the National Comorbidity Survey. Arch Gen Psychiatry 52: 219-229. CrossRef Medline
Wassum KM, Izquierdo A (2015) The basolateral amygdala in reward learning and addiction. Neurosci Biobehav Rev 57:271-283. CrossRef Medline

Whitaker LR, Degoulet M, Morikawa H (2013) Social deprivation enhances VTA synaptic plasticity and drug-induced contextual learning. Neuron 77:335-345. CrossRef Medline

Whitsett JM (1975) The development of aggressive and marking behavior in intact and castrated male hamsters. Horm Behav 6:47-57. CrossRef Medline

Whitsett JM, Miller LL (1982) Photoperiod and reproduction in female deer mice. Biol Reprod 26:296-304. CrossRef Medline

Wilkinson LS, Killcross SS, Humby T, Hall FS, Geyer MA, Robbins TW (1994) Social isolation in the rat produces developmentally specific deficits in prepulse inhibition of the acoustic startle response without disrupting latent inhibition. Neuropsychopharmacology 10:61-72. CrossRef Medline

Willing J, Juraska JM (2015) The timing of neuronal loss across adolescence in the medial prefrontal cortex of male and female rats. Neuroscience 301:268-275. CrossRef Medline

Willing J, Drzewiecki CM, Cuenod BA, Cortes LR, Juraska JM (2016) A role for puberty in water maze performance in male and female rats. Behav Neurosci 130:422-427. CrossRef Medline

Willing J, Cortes LR, Brodsky JM, Kim T, Juraska JM (2017) Innervation of the medial prefrontal cortex by tyrosine hydroxylase immunoreactive fibers during adolescence in male and female rats. Dev Psychobiol 59: 583-589. CrossRef Medline

Wingo T, Nesil T, Choi JS, Li MD (2016) Novelty seeking and drug addiction in humans and animals: from behavior to molecules. J Neuroimmune Pharmacol 11:456-470. CrossRef Medline

Wommack JC, Delville Y (2007) Stress, aggression, and puberty: neuroendocrine correlates of the development of agonistic behavior in golden hamsters. Brain Behav Evol 70:267-273. CrossRef Medline

Wright IK, Upton N, Marsden CA (1991a) Resocialisation of isolationreared rats does not alter their anxiogenic profile on the elevated X-maze model of anxiety. Physiol Behav 50:1129-1132. CrossRef Medline

Wright IK, Ismail H, Upton N, Marsden CA (1991b) Effect of isolation rearing on 5-HT agonist-induced responses in the rat. Psychopharmacology (Berl) 105:259-263. CrossRef Medline

Yates JR, Beckmann JS, Meyer AC, Bardo MT (2013) Concurrent choice for social interaction and amphetamine using conditioned place preference in rats: effects of age and housing condition. Drug Alcohol Depend 129: 240-246. CrossRef Medline

Yellon SM, Goldman BD (1984) Photoperiod control of reproductive development in the male Djungarian hamster (Phodopus sungorus). Endocrinology 114:664-670. CrossRef Medline

Zuo XN, Kelly C, Di Martino A, Mennes M, Margulies DS, Bangaru S, Grzadzinski R, Evans AC, Zang YF, Castellanos FX, Milham MP (2010) Growing together and growing apart: regional and sex differences in the lifespan developmental trajectories of functional homotopy. J Neurosci 30:15034-15043. CrossRef Medline 